\title{
Effect of maternal yeast feeding on dam performance and serum health biomarkers of Beetal goat kids
}

\author{
S. Abbas' ${ }^{1}$, M.A. Rashid ${ }^{4}$, M.S. Yousaf', S. Ashraf', I. Rabbani' ${ }^{1}$, H. Zaneb², S.K. Tahir ${ }^{1}$, A.H. \\ Shahzad ${ }^{3}$ \& H. Rehman ${ }^{1 \#}$ \\ ${ }^{1}$ Department of Physiology, University of Veterinary and Animal Sciences, Lahore 54000, Pakistan \\ 2Department of Anatomy and Histology, University of Veterinary and Animal Sciences, Lahore 54000, Pakistan \\ ${ }^{3}$ Department of Clinical Sciences, University of Veterinary and Animal Sciences Sub-campus, Jhang 35200, Pakistan \\ ${ }^{4}$ Department of Animal Nutrition, University of Veterinary and Animal Sciences, Lahore 54000, Pakistan.
}

(Received 5 September 2019; Accepted 14 April 2020; First published online 18 May 2020)

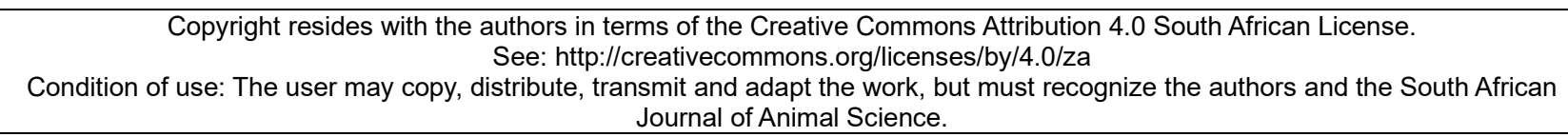
Journal of Animal Science.

\begin{abstract}
Supplementation with dietary yeast has improved digestibility and productive performance in ruminants. In this research the primary objective was to appraise the effects of dietary yeast supplementation of female goats during the transition period on milk composition and yield and on production and serum health biomarkers of their kids. Twenty-four Beetal goats ( $4 \pm 1.2$ years) were randomly assigned to three groups, which received 0,5 , and 10 grams/animal/day of live dried yeast Saccharomyces cerevisiae for 60 days ( 30 days pre- and post-partum). All goats were fed 500 grams of concentrate with water and green fodder ad libitum. Milk samples were collected at 7, 14, 21, and 28 days post kidding. Kids were weighed on days $0,7,15,22$, and 30 , and blood samples were collected on days 15 and 30 for serum metabolites (glucose, urea, cholesterol, non-esterified fatty acids (NEFA), serum total proteins, albumin, globulin, albumin to globulin ratio, serum oxidant and antioxidant activity (malondialdehyde) (MDA) and catalase), and liver enzymes aspartate aminotransferase (AST) and alanine transaminase (ALT) assessment. Milk yield was significantly $(P=0.02)$ higher during the post-partum period in yeast-fed goats. Yeast-fed goats also produced milk containing more fat $(P<0.001)$ and protein $(P<0.001)$ compared with control goats. Birth weight, average daily gain, and serum health biomarkers of the kids were not influenced by the treatments. In conclusion, dietary yeast supplementation resulted in increased production performance of the dams without significant impact on their offspring.
\end{abstract}

Keywords: average daily gain, catalase activity, hepatic enzymes, milk production, Saccharomyces cerevisiae, transition period

\#Corresponding author: habibrehman@uvas.edu.pk

\section{Introduction}

The transition period, from 3 weeks before until 3 weeks after parturition, is a stressful time in the life of a goat, similarly to other ruminants. Increased energy demands and low feed intake make the body of the dam prone to a negative energy balance in particular during this period. Negative energy balances can lead to metabolic derangements and health issues for the dams. Moreover, the nutritional status of the dam during the transition phase in particular has been revealed to have a strong impact on the development, growth and viability of their offspring in pre- and post-natal life in many species (Hansen et al., 2012; Faubladier et al., 2013). Birth weight is a significant predictor of future health outcomes of a kid. Kids born with lower than optimum birth weights usually have low energy reserves, decreased thermoregulatory capacity, and increased mortality probability (Alkass et al., 2013). It is well documented that the birth weight of a kid is strongly affected by the feeding of the dam during the gestation period (Otuma \& Osakwe, 2008). Thus, energy reserves at birth are fundamental to ensuring neonatal survival (Theil et al., 2014). The perinatal period is related to sudden changes in energy supply. Subsequently neonates rely exclusively on body energy reserves to maintain glucose homeostasis until the ingestion of colostrum and milk can meet their energy demands (Xie et al., 2015). Neonatal goat kids require regular nursing and substantial gluconeogenesis to maintain normoglycemia. 
Yeast, as a probiotic, is well known for its positive effects on the gut, metabolic health status and overall wellbeing of the host animal, particularly during stressful conditions. Although the use of yeast as a feed supplement has been well documented in large ruminants during the transition period (Nocek \& Kautz, 2014), data about its use in transition goats are limited. A meta-analysis of 61 studies by Poppy et al. (2012) found that under normal environmental conditions, milk production and composition were improved with yeast supplementation in dairy cattle (Bitencourt et al., 2011). A number of studies reported a higher serum glucose concentration (Lesmeister et al., 2004), lower NEFA (Dolezal et al., 2005), increased blood urea nitrogen, and increased total protein (Galip, 2006) in animals supplemented with yeast.

The maternal diet has been shown to affect the growth and development of their progeny in various species, including goats, sheep and horses (Abu El-Ella et al., 2013; Alkass et al., 2013; Faubladier et al., 2013). However, there is scarcity of data about the effects on the productive performance and health biomarkers in goat kids of a maternal diet supplemented with varying levels of yeast during the transition period. It was hypothesized that various inclusion levels of dietary yeast to Beetal goats during late gestation and early lactation would affect the health and performance of goats and subsequently the suckling kids that are raised along with their dams. Therefore, the objectives of present study were to examine the effects of live yeast on milk production and its composition in Beetal goats and to evaluate the impact of maternal dietary yeast supplementation on kid weight, average daily gain, serum metabolites, serum protein profile, oxidant and antioxidant status and liver enzymes during the first 30 days of their lives.

\section{Materials and Methods}

The experiment was conducted at the Small Ruminant Research Centre Pattoki, University of Veterinary and Animal Sciences, Lahore-Pakistan. The duration of the study was 60 days, and was conducted over the transition period, which included four weeks before kidding ( $28 \pm 2$ days) and four weeks (28 \pm 2 days) afterwards. The study site is located at latitude 31.057254 (north), longitude 73.878469 (east) and altitude (above sea level) of 186 metres with an average annual rainfall of $550-600$ millimetres and an average mean temperature of $23^{\circ} \mathrm{C}$. All the protocols for the general care, handling and maintenance of animals during the study period were approved by the Ethical Committee for the Use of Animals of the University (No. DR/309, 24 June 2016).

All goats were fed a basal pre-partum diet, which consisted of berseem clover (Trifolium alexandrinum L.) as green fodder twice daily and a concentrate mixture (Table 1), which was fed once a day before kidding and twice daily after kidding. Enough green fodder was offered to the goats to provide for approximately $5 \%$ feed refusals (as-fed basis) during the pre-partum period. Feed offered and feed refused were measured daily. After kidding, all goats were offered a post-partum (lactation) diet (Table 1) but remained on the same yeast treatment to which they were first assigned. Goats were offered the post-partum diet twice daily to allow approximately $10 \%$ feed refusals (as-fed basis). Dry matter intake (DMI) was measured daily by subtracting the feed offered to goats from the feed leftover. The data of the daily DMI were used to calculate the weekly DMI of goats. Samples of diet were subjected biweekly to analysis of dry matter using the AOAC (2005) method.

All kiddings were attended and observed by trained personnel. A total of 31 kids were born from 24 goats that had previously been synchronized with OvSynch protocol (19 single and 6 twin births). Immediately after birth, all the kids were weighed, given an identification number, and allowed to stay with their mother for first 48 hours post kidding. Sufficient colostrum consumption by each kid was ensured personally within the first 48 hours of life. The median date of birth of the kids was 13 February, and the mean kid BW at birth was $3.3 \pm 1.2 \mathrm{~kg}$.

At 48 hours post parturition, only one kid was maintained with the dam and the twin was separated and excluded from the study. The counterpart twin kid was separated randomly and reared on a nursing goat. The study population of the resulting kids consisted of 24 Beetal kids. Based on the maternal supplementation levels of yeast, the newborn kids were assigned to one of three experimental treatment groups, namely YSC0, YSC5, and YSC10 (fed 0, 5, and 10 grams/animal/day of live dried yeast Saccharomyces cervisiae), with each treatment having eight kids. All the kids were placed with their dams from birth until the end of the experiment (one month) and had free access to dam milk except on the day of week that her milk yield was measured. Dams were kept in individual pens. Fresh water was made available. Kids were offered green fodder and concentrate ad libitum from day 15 until the conclusion of study. 
Table 1 Ingredients and chemical composition of basal pre-partum and post-partum diets fed to the goats during transition period

\begin{tabular}{lcc}
\hline & & Basal diets \\
\cline { 2 - 3 } & Pre-partum & Post-partum \\
\hline Ingredients (dry matter basis, \%) & & 60 \\
Berseem and wheat straw & 70 & 40 \\
Concentrate mixture & 30 & 15.0 \\
Concentrate mixture, \% & & 8.0 \\
Maize grain (crushed) & 15.0 & 20.0 \\
Cottonseed cake & 16.0 & 20.0 \\
Cottonseed meal & & 15.5 \\
Maize gluten 30\% & 20.0 & 1.5 \\
Wheat bran & 15.0 & 18.0 \\
Rice bran meal & 13.0 & 2.0 \\
Urea & 1.0 & 3.0 \\
Molasses & 18.0 & 85.0 \\
Mineral and vitamin premixes ${ }^{1}$ & 2.0 & 17.6 \\
Nutritional profile on dry matter basis (\%) & & 70.0 \\
Dry matter, \% & 85.0 & 3.0 \\
Crude protein, \% & 16.7 & \\
Total digestible nutrients, \% & 69.5 & \\
Metabolizable energy, Mcal/kg & & \\
\end{tabular}

${ }^{1}$ Mineral mixture contained Di-Calcium phosphate (DCP), common salt, magnesium sulphate, ferrous sulphate, manganese sulphate, zinc sulphate, copper sulphate, potassium iodide, cobalt chloride, and sodium selenate. The vitamin premix had $700,000 \mathrm{IU} / \mathrm{kg}$ vitamin $\mathrm{A}, 66,000 \mathrm{IU} / \mathrm{kg}$ vitamin D and $2000 \mathrm{mg} / \mathrm{kg}$ vitamin $\mathrm{E}$

Milk yield and milk samples were collected and measured by isolating the suckling kids from their dams for two consecutive milkings, that is, from the evening milking on the day before to the end of the evening milking on the subsequent day. The isolated kids were fed their own dam's milk after sample collection. During the post-partum lactation phase, the milk yield of each goat was recorded once a week. The individual milk samples were collected on days $7,14,21$, and 28 of lactation, and an aliquot was subsequently analysed for milk fat, protein, lactose, solids-not-fat (SNF) percentage and $\mathrm{pH}$ by an infrared analyser (MilkoScan 4000, Foss, Hillerød, Denmark).

Two blood samples were collected from each kid at 15 and 30 days old. All samples were collected prior to the morning feeding. Briefly, $4 \mathrm{~mL}$ blood was taken from the jugular vein in a plain vacutainer from each kid. The serum was harvested by centrifugation at $3000 \mathrm{rpm}$ for 20 minutes soon after collection. Paired sera samples from each kid were collected in two separate Eppendorf tubes, which were labelled and stored at $-20^{\circ} \mathrm{C}$ until further analysis. One sample was utilized for serum metabolite glucose (Cat. no. GL 2623), urea, cholesterol (Cat. no. CH 293), protein profile, total proteins (Cat. no. TP 245), and albumin (Cat. no. AB 362) (Randox Laboratories Limited, Antrim, NI). Oxidative stress biomarkers were assessed with assay kits, namely malondialdehyde (Cat. no. MAK085, Sigma-Aldrich), catalase (Cat. no. CAT100, SigmaAldrich), and liver enzymes such as AST and ALT (AS 147 and AL 146) 9Randox Laboratories Ltd., Antrim, $\mathrm{NI}$ ). The other serum sample was utilized for NEFA determination with a commercial kit (Cat. no. FA 115) (Randox Laboratories Ltd., Crumlin, Co. Antrim, NI).

Data were analysed with SPSS version 21 for Windows (IBM SPSS ${ }^{\circledR}$ software, Chicago, USA, 2012). The milk production, milk composition of goats and serum metabolites of kids were analysed using repeated measures analysis of variance (ANOVA). Significance was determined using goats within treatment as the error term. For significant F-values, means were separated using Tukey's procedure. Significance level was set at $(P<0.05)$ and the results were presented as mean \pm SEM. 


\section{Results and Discussion}

The results of the current study showed that goats of YSC5 and YSC10 groups had higher $(P=0.02)$ milk yield compared with the YSC0 group during the post-partum period, while treatment and day interaction was not significant. Furthermore, the milk yield increased consistently $(P=0.01)$ from the first to fourth week of lactation (post-partum) in goats of all groups. However, the yeast-supplemented groups showed better milk yield compared with the non-supplemented group.

Weekly milk samples were collected from the goats and analysed for milk protein, fat, lactose, SNF percentage and milk $\mathrm{pH}$. The effects of various inclusion levels of yeast on the milk composition profile of early post-partum goats are presented in Table 2 and 3.

Table 2 Effect of varying inclusion levels of Saccharomyces cerevisiae on milk yield, protein content and fat content in goats during post-partum period

\begin{tabular}{|c|c|c|c|c|c|c|c|c|}
\hline \multirow{2}{*}{ Variable } & \multirow{2}{*}{$\begin{array}{l}\text { Post-partum } \\
\text { period, days }\end{array}$} & \multicolumn{3}{|c|}{ Treatment $^{1}$} & \multirow{2}{*}{ SEM } & \multicolumn{3}{|c|}{$P$-value } \\
\hline & & YSCO & YSC5 & YSC10 & & Treatment & Day & $\begin{array}{c}\text { Treatment } x \\
\text { day }\end{array}$ \\
\hline \multirow{5}{*}{$\begin{array}{l}\text { Milk yield } \\
(\mathrm{mL} / \mathrm{d})\end{array}$} & 1 to 7 & 317.25 & 361.87 & 407.33 & 14.09 & \multirow{4}{*}{0.02} & \multirow{5}{*}{0.01} & \multirow{5}{*}{0.49} \\
\hline & 8 to14 & 336.75 & 393.75 & 421.11 & 12.78 & & & \\
\hline & 15 to 21 & 331.37 & 395.50 & 406.33 & 12.81 & & & \\
\hline & 22 to 28 & 344.37 & 388.75 & 401.44 & 10.72 & & & \\
\hline & 1 to 7 & $3.92^{\mathrm{b}}$ & $4.11^{\mathrm{a}}$ & $4.13^{a}$ & 0.06 & \multirow{4}{*}{$<0.001$} & & \\
\hline \multirow{3}{*}{$\begin{array}{l}\text { Protein } \\
(\%)\end{array}$} & 8 to 14 & $3.79^{b}$ & $4.45^{\mathrm{a}}$ & $4.39^{a}$ & 0.08 & & \multirow{3}{*}{$<0.001$} & \multirow{3}{*}{$<0.001$} \\
\hline & 15 to 21 & $3.52^{b}$ & $4.18^{\mathrm{a}}$ & $4.20^{\mathrm{a}}$ & 0.01 & & & \\
\hline & 22 to 28 & $3.37^{b}$ & $4.28^{\mathrm{a}}$ & $4.24^{\mathrm{a}}$ & 0.02 & & & \\
\hline \multirow{4}{*}{ Fat $\%$} & 0 to 7 & $4.41^{b}$ & $4.69^{a}$ & $4.68^{a}$ & 0.02 & \multirow{4}{*}{$<0.001$} & \multirow{4}{*}{$<0.001$} & \multirow{4}{*}{0.004} \\
\hline & 8 to 14 & $4.47^{b}$ & $4.79^{a}$ & $4.80^{\mathrm{a}}$ & 0.05 & & & \\
\hline & 15 to 21 & $4.45^{b}$ & $4.89^{a}$ & $4.87^{a}$ & 0.03 & & & \\
\hline & 22 to 28 & $4.68^{b}$ & $4.99^{a}$ & $4.90^{a}$ & 0.02 & & & \\
\hline
\end{tabular}

1YSC0: unsupplemented control, YSC5: supplemented with 5 g per day Saccharomyces cerevisiae, YSC10: supplemented with $10 \mathrm{~g}$ per day Saccharomyces cerevisiae

a,b,c Within a row, means with a common superscript did not differ at $P=0.05$

The significant treatment and day interaction $(P<0.001)$ showed that the yeast-supplemented goats had higher $(P<0.001)$ milk protein content compared with the non-supplemented goats. Likewise, the sampling day effect was significant $(P<0.001)$ within the groups represented by an increase in milk protein percentage (Table 2). The results of the current experiment showed that milk fat content was influenced positively by the various inclusion levels of yeast during the first four weeks post-partum. The significant $(P$ $=0.004$ ) treatment and days interaction showed that although the milk fat content increased gradually from the first to the fourth week of the post-partum period in all goats, the yeast- supplemented goats had higher milk fat percentage compared with the non-supplemented goats.

There were no significant differences in milk lactose content and milk pH between yeast-supplemented and non-supplemented goats during the post-partum period. However, the yeast-fed goats showed a nonsignificant tendency for low SNF content compared with the control goats during the same period. In contrast to treatment effect, the milk lactose content decreased $(P<0.001)$ gradually and the SNF content increased $(P<0.001)$ consistently within the groups over the four weeks. The results of milk lactose content, SNF content and milk pH are presented in Table 3. 
Table 3 Effect of varying inclusion levels of Saccharomyces cerevisiae on milk composition in goats during post-partum period

\begin{tabular}{|c|c|c|c|c|c|c|c|c|}
\hline \multirow{2}{*}{ Item } & \multirow{2}{*}{$\begin{array}{l}\text { Days post- } \\
\text { partum }\end{array}$} & \multicolumn{3}{|c|}{ Treatment $^{1}$} & \multirow{2}{*}{ SEM } & \multicolumn{3}{|c|}{$P$-value } \\
\hline & & YSC0 & YSC5 & YSC10 & & Treatment & Day & $\begin{array}{c}\text { Treatment } \\
\text { x day }\end{array}$ \\
\hline \multirow{6}{*}{ Lactose \% } & 7 & 4.54 & 4.55 & 4.54 & 0.03 & & & \\
\hline & 14 & 4.49 & 4.44 & 4.43 & 0.02 & & & \\
\hline & 21 & 4.39 & 4.37 & 4.39 & 0.04 & & & \\
\hline & 28 & 4.33 & 4.31 & 4.29 & 0.03 & & & \\
\hline & $7 d$ to $28 d$ & 4.43 & 4.41 & 4.41 & 0.04 & 0.30 & $<0.001$ & 0.10 \\
\hline & 7 & 8.09 & 8.01 & 8.05 & 0.04 & & & \\
\hline \multirow{3}{*}{$\begin{array}{l}\text { Solids Not } \\
\text { Fat } \%\end{array}$} & 14 & 8.10 & 8.06 & 8.07 & 0.08 & & & \\
\hline & 21 & 8.09 & 8.04 & 8.11 & 0.05 & & & \\
\hline & 28 & 8.21 & 8.20 & 8.20 & 0.02 & & & \\
\hline \multirow{6}{*}{$\mathrm{pH}$} & $7 d$ to $28 d$ & 8.12 & 8.07 & 8.10 & 0.03 & 0.09 & $<0.001$ & 0.52 \\
\hline & 7 & 6.65 & 6.66 & 6.68 & 0.01 & & & \\
\hline & 14 & 6.68 & 6.69 & 6.67 & 0.09 & & & \\
\hline & 21 & 6.70 & 6.67 & 6.68 & 0.02 & & & \\
\hline & 28 & 6.67 & 6.66 & 6.67 & 0.03 & & & \\
\hline & $7 d$ to $28 d$ & 6.67 & 6.67 & 6.67 & 0.04 & 0.99 & 0.74 & 0.89 \\
\hline
\end{tabular}

1YSC0: unsupplemented control, YSC5: supplemented with $5 \mathrm{~g}$ per day Saccharomyces cerevisiae, YSC10: supplemented with $10 \mathrm{~g}$ per day Saccharomyces cerevisiae

The performances of the kids born to yeast-supplemented and to non-yeast-supplemented goats were measured in terms of birth weight, average daily gain from birth to 30 days old (Table 4). Birth weight and ADG of suckling kids were not significantly different between the goats supplemented with yeast and control.

Table 4 Effect of varying inclusion levels of Saccharomyces cerevisiae (yeast) in transition goat on the body weight $(\mathrm{kg})$ and average daily gain $(\mathrm{g})$ of their suckling kids

\begin{tabular}{|c|c|c|c|c|c|c|c|c|}
\hline \multirow{2}{*}{ Item } & \multirow{2}{*}{$\begin{array}{l}\text { Age of kid } \\
\text { (weeks) }\end{array}$} & \multicolumn{3}{|c|}{ Treatment $^{1}$} & \multirow[b]{2}{*}{ SEM } & \multicolumn{3}{|c|}{$P$-value } \\
\hline & & YSCO & YSC5 & YSC10 & & Treatment & Day & $\begin{array}{c}\text { Treatment } \\
\times \text { day }\end{array}$ \\
\hline \multirow[t]{4}{*}{ Birth weight } & 0 & 3.18 & 3.43 & 3.40 & 0.24 & & & \\
\hline & 1 & 4.55 & 5.40 & 4.85 & 0.38 & & & \\
\hline & 2 & 4.81 & 5.45 & 4.66 & 0.54 & & & \\
\hline & 3 & 5.07 & 6.05 & 5.10 & 0.53 & & & \\
\hline Final bodyweight & 4 & 5.61 & 6.36 & 6.13 & 0.59 & & & \\
\hline $\begin{array}{l}\text { Average weight } \\
\text { weight/week }\end{array}$ & $0-4$ & 4.64 & 5.34 & 4.83 & 0.41 & 0.48 & $<0.001$ & 0.51 \\
\hline Average daily gain & $0-4$ & 80.81 & 97.81 & 91.25 & 9.44 & 0.77 & & \\
\hline
\end{tabular}

1YSC0: unsupplemented control, YSC5: supplemented with $5 \mathrm{~g}$ per day Saccharomyces cerevisiae, YSC10: supplemented with $10 \mathrm{~g}$ per day Saccharomyces cerevisiae

The blood samples of the suckling kids were collected at 15 and 30 days old. The results of the present study showed that serum metabolites (glucose, NEFA, urea nitrogen and cholesterol) were not affected by their dam's treatment level during their first 30 days. Unlike the treatment effect, the mean NEFA 
concentration decreased significantly on day 30 compared with day 15 in all kids. However, the other serum metabolites were not affected by the sampling day. The results of health biomarkers are presented in Tables 5 and 6.

Table 5 Effect of varying inclusion levels of Saccharomyces cerevisiae (yeast) in transition goats on the serum metabolites of their suckling kids

\begin{tabular}{|c|c|c|c|c|c|c|c|c|}
\hline \multirow{2}{*}{ Item } & \multirow{2}{*}{$\begin{array}{l}\text { Age of kid } \\
\text { (days) }\end{array}$} & \multicolumn{3}{|c|}{ Treatment $^{1}$} & \multirow{2}{*}{ SEM } & \multicolumn{3}{|c|}{$P$-value } \\
\hline & & YSCO & YSC5 & YSC10 & & Treatment & Day & $\begin{array}{c}\text { Treatment } \\
\mathrm{x} \text { day }\end{array}$ \\
\hline \multirow{3}{*}{$\begin{array}{l}\text { Glucose } \\
\mathrm{mmol} / \mathrm{L}\end{array}$} & $15 d$ & 3.08 & 3.10 & 2.94 & 0.36 & & & \\
\hline & $30 \mathrm{~d}$ & 2.75 & 2.81 & 2.98 & 0.35 & & & \\
\hline & $15 \mathrm{~d}$ and $30 \mathrm{~d}$ & 2.92 & 2.95 & 2.96 & 0.31 & 0.99 & 0.34 & 0.71 \\
\hline \multirow{3}{*}{$\begin{array}{l}\text { Urea nitrogen } \\
\mathrm{mmol} / \mathrm{L}\end{array}$} & $15 d$ & 4.86 & 4.58 & 5.22 & 0.51 & & & \\
\hline & $30 \mathrm{~d}$ & 4.32 & 4.47 & 4.90 & 0.45 & & & \\
\hline & $15 d$ to $30 d$ & 4.59 & 4.53 & 5.06 & 0.28 & 0.36 & 0.48 & 0.93 \\
\hline \multirow{3}{*}{$\begin{array}{l}\mathrm{NEFA} \\
\mathrm{mmol} / \mathrm{L}\end{array}$} & $15 d$ & 0.034 & 0.036 & 0.037 & 0.003 & & & \\
\hline & $30 d$ & 0.031 & 0.030 & 0.031 & 0.002 & & & \\
\hline & $15 d$ to $30 d$ & 0.033 & 0.033 & 0.035 & 0.002 & 0.75 & 0.02 & 0.74 \\
\hline \multirow{3}{*}{$\begin{array}{l}\text { Cholesterol } \\
\mathrm{mmol} / \mathrm{L}\end{array}$} & $15 d$ & 1.37 & 1.36 & 1.29 & 0.16 & & & \\
\hline & $30 d$ & 1.46 & 1.67 & 1.35 & 0.18 & & & \\
\hline & $15 d$ to $30 d$ & 1.41 & 1.52 & 1.32 & 0.14 & 0.62 & 0.21 & 0.65 \\
\hline
\end{tabular}

\footnotetext{
'YSC0: unsupplemented control, YSC5: supplemented with $5 \mathrm{~g}$ per day Saccharomyces cerevisiae, YSC10: supplemented with $10 \mathrm{~g}$ per day Saccharomyces cerevisiae

NEFA: non-esterified fatty acids
}

Table 6 Effect of varying levels of inclusion of Saccharomyces cerevisiae (yeast) in transition goat on serum protein profile of their suckling kids

\begin{tabular}{|c|c|c|c|c|c|c|c|c|}
\hline \multirow{2}{*}{ Item } & \multirow{2}{*}{$\begin{array}{l}\text { Age of kid } \\
\text { (days) }\end{array}$} & \multicolumn{3}{|c|}{ Treatment $^{1}$} & \multirow{2}{*}{ SEM } & \multicolumn{3}{|c|}{$P$-value } \\
\hline & & YSCO & $\begin{array}{l}\text { YS } \\
\text { C5 } \\
\end{array}$ & YSC10 & & Treatment & Day & $\begin{array}{c}\text { Treatment } \mathrm{x} \\
\text { day }\end{array}$ \\
\hline \multirow{3}{*}{$\begin{array}{l}\text { Total proteins } \\
(\mathrm{g} / \mathrm{dL})\end{array}$} & $15 d$ & 5.13 & 5.05 & 5.03 & 0.18 & & & \\
\hline & $30 \mathrm{~d}$ & 5.70 & 5.83 & 5.56 & 0.15 & & & \\
\hline & $15 d$ to $30 d$ & 5.42 & 5.44 & 5.29 & 0.10 & 0.58 & $<0.001$ & 0.74 \\
\hline \multirow{3}{*}{$\begin{array}{l}\text { Albumin } \\
(\mathrm{g} / \mathrm{dL})\end{array}$} & $15 d$ & 2.73 & 2.43 & 2.65 & 0.10 & & & \\
\hline & $30 \mathrm{~d}$ & 2.96 & 3.16 & 2.98 & 0.09 & & & \\
\hline & $15 d$ to $30 d$ & 2.85 & 2.79 & 2.82 & 0.06 & 0.83 & $<0.001$ & 0.06 \\
\hline \multirow{3}{*}{$\begin{array}{l}\text { Globulin } \\
(\mathrm{g} / \mathrm{dL})\end{array}$} & $15 d$ & 2.40 & 2.62 & 2.38 & 0.14 & & & \\
\hline & $30 \mathrm{~d}$ & 2.73 & 2.66 & 2.57 & 0.08 & & & \\
\hline & $15 d$ to $30 d$ & 2.57 & 2.64 & 2.47 & 0.07 & 0.28 & 0.08 & 0.52 \\
\hline \multirow{3}{*}{$\begin{array}{l}\text { Albumin } \\
\text { /globulin }\end{array}$} & $15 d$ & 1.14 & 0.98 & 1.12 & 0.07 & & & \\
\hline & $30 d$ & 1.08 & 1.12 & 1.16 & 0.03 & & & \\
\hline & $15 d$ to $30 d$ & 1.11 & 1.08 & 1.14 & 0.03 & 0.43 & 0.23 & 0.12 \\
\hline
\end{tabular}

\footnotetext{
1YSC0: unsupplemented control, YSC5: supplemented with $5 \mathrm{~g}$ per day Saccharomyces cerevisiae, YSC10: supplemented with $10 \mathrm{~g}$ per day Saccharomyces cerevisiae
} 
The present study showed that serum protein profiles of kids were not affected by their dams' yeast inclusion levels during their first 30 days. However, the serum total protein, albumin and globulin concentration increased significantly $(P<0.001)$ with advancement of age of kids within the groups. However, the albumin to globulin ratio was not affected by the age of the kids. The kid serum protein profile included total proteins, albumin, globulin, albumin to globulin ratio (Table 6).

The serum MDA and catalase concentration of the kids born to the yeast-supplemented dams were not significantly different compared with the kids of the control dams on day 15 and day 30 . The serum MDA level was not significantly $(P=0.07)$ reduced, while catalase activity was increased $(P=0.009)$ from birth to 30 days old in all kids. The results of MDA and catalase status in kids are presented in Table 7.

Table 7 Effect of varying inclusion levels of Saccharomyces cerevisiae (yeast) in transition goat on serum oxidant and antioxidant profile of their suckling kids

\begin{tabular}{|c|c|c|c|c|c|c|c|c|}
\hline \multirow{2}{*}{ Item } & \multirow{2}{*}{$\begin{array}{l}\text { Age of kid } \\
\text { (days) }\end{array}$} & \multicolumn{3}{|c|}{ Treatment $^{1}$} & \multirow{2}{*}{ SEM } & \multicolumn{3}{|c|}{$P$-value } \\
\hline & & YSC0 & YSC5 & YSC10 & & Treatment & Day & $\begin{array}{c}\text { Treatment } x \\
\text { day }\end{array}$ \\
\hline \multirow{3}{*}{$\begin{array}{c}\mathrm{MDA} \\
\mu \mathrm{mol} / \mathrm{L}\end{array}$} & $15 d$ & 0.38 & 0.36 & 0.34 & 0.05 & & & \\
\hline & $30 d$ & 0.33 & 0.27 & 0.27 & 0.06 & & & \\
\hline & $15 d$ to $30 d$ & 0.35 & 0.31 & 0.30 & 0.04 & 0.70 & 0.07 & 0.87 \\
\hline \multirow{3}{*}{$\begin{array}{l}\text { CAT } \\
\text { U/L }\end{array}$} & $15 d$ & 49.72 & 51.36 & 53.58 & 2.34 & & & \\
\hline & $30 d$ & 53.87 & 57.88 & 57.37 & 3.16 & & & \\
\hline & $15 d$ to $30 d$ & 51.80 & 54.62 & 55.47 & 2.37 & 0.52 & 0.009 & 0.77 \\
\hline
\end{tabular}

'YSC0: unsupplemented control, YSC5: supplemented with $5 \mathrm{~g}$ per day Saccharomyces cerevisiae, YSC10: supplemented with $10 \mathrm{~g}$ per day Saccharomyces cerevisiae

MDA: malondialdehyde; CAT: catalase

Supplementation of dams with yeast did not affect the serum AST and ALT concentration of their kids during the first 30 days of their postnatal life (Table 8). Likewise, the liver enzyme concentrations of different groups were not significantly different on different sampling days.

Table 8 Effect of varying inclusion levels of Saccharomyces cerevisiae (yeast) in transition goat on serum liver enzymes profile of their suckling kids

\begin{tabular}{ccccccccc}
\hline \multirow{2}{*}{ Item } & \multirow{2}{*}{$\begin{array}{c}\text { Age of } \\
\text { kid(days) }\end{array}$} & \multicolumn{3}{c}{ Treatment $^{1}$} & & \multicolumn{3}{c}{$P$-value } \\
& YSC0 & YSC5 & YSC10 & & Treatment & Day & $\begin{array}{c}\text { Treatment } x \\
\text { day }\end{array}$ \\
\hline \multirow{2}{*}{ AST } & $15 \mathrm{~d}$ & 62.07 & 61.11 & 61.69 & 3.40 & & & \\
(ULI) & $30 \mathrm{~d}$ & 58.94 & 58.28 & 60.49 & 2.75 & & & \\
& $15 \mathrm{~d}$ to $30 \mathrm{~d}$ & 60.51 & 59.70 & 61.09 & 2.36 & 0.91 & 0.32 & 0.93 \\
ALT & $15 \mathrm{~d}$ & 23.45 & 24.02 & 24.86 & 0.93 & & & \\
(U/L) & $30 \mathrm{~d}$ & 23.44 & 24.73 & 24.92 & 0.54 & & & \\
& 15 d to 30 d & 23.44 & 24.37 & 24.89 & 0.58 & 0.23 & 0.85 & 0.66
\end{tabular}

1YSC0: unsupplemented control, YSC5: supplemented with $5 \mathrm{~g}$ per day Saccharomyces cerevisiae, YSC10: supplemented with $10 \mathrm{~g}$ per day Saccharomyces cerevisiae

AST: aspartate aminotransferase, ALT: alanine aminotransferase

This study aimed to assess whether dietary yeast supplementation would affect the milk yield, milk composition of transition goats and the subsequent birth weight, average daily gain and serum heath biomarkers of their suckling kids. The yeast-fed goats of the present study produced more milk compared 
with control goats during the post-partum period. These findings agree with a number of studies that reported a higher milk yield in dairy goats supplemented with yeast (Abd El-Ghani, 2004; Giger-Reverdin et al., 1996; Stella et al., 2007). It was hypothesized that yeast-induced improvement in DMI resulted in better body reserves, which were eventually translated into greater milk production by providing better nutrient flow to the mammary glands (Campanile et al., 2008). The results of the present study indicated that yeast-fed goats had higher milk fat content compared with the control goats during the post-partum period. Similarly, GigerReverdin et al. (1996) reported a higher milk fat content in yeast-fed lactating goats. It is well established that energy status of an animal affects both milk yield and composition. The greater milk fat content observed in the current study might be due to better utilization of the very low-density lipoprotein (VLDL) and circulating NEFA by the mammary glands (Drackley et al., 2006). Moreover, this hypothesis is supported by a significantly low level of NEFA and high glucose concentration in the yeast-supplemented goats compared with the non-supplemented goats during the post-partum period as observed in the current study.

Higher milk protein content was observed in yeast-supplemented goats compared with the nonsupplemented goats in present study. The current findings are supported by a number of studies in lactating cows (Erasmus et al., 1992; Wohlt et al., 1998). The observed increase in milk protein content probably resulted from yeast-induced better bioavailability of lysine and methionine in the duodenum (Erasmus et al., 1992). Methionine and lysine are the most limiting factors for milk protein synthesis in dairy cows (Guinard et al., 1994). Thus, better bioavailability of these amino acids in the duodenum could lead to their enhanced extraction from blood by the mammary glands and use for greater milk protein synthesis (Jenkins \& McGuire, 2006).

The lack of improvement in milk lactose content, SNF content and milk pH in current study agrees with the findings of Stella et al. (2007) and Salama et al. (2002) in dairy goat during early lactation. In the current study, yeast supplementation improved serum glucose levels in the post-partum period. However, it did not translate into increased milk lactose content. Although milk lactose synthesis depends primarily on serum glucose of the dam, the mammary gland has the ability to synthesize normal lactose, even in a hypoglycemic dam (Kaneko et al., 2008), which indicates that dams might not be benefitting from extraneous sources of glucose precursors for increased milk lactose content. Stage of lactation, composition of diet, fodder concentrate ratio and breed of the animal are among the factors that can affect the response of animals to yeast supplementation (Ngwa et al., 2009).

The results of the present study showed that various levels of dietary yeast supplementation to transition goats did not have significant effects on the mean birth weight and average daily weight gain of their kids. Similar to the current report, Share (2015) did not observe beneficial effects of maternal yeast supplementation during the transition period on the birth weight and ADG of their foals. In contrast to the current study, Abu El-Ella and Kommonna (2013) reported a higher birth weight and average daily gain in the kids born to yeast-fed goats during the whole gestation period. Compared with the current study, Abu El Ella and Kommonna (2013) fed the goats with yeast from pre-mating until the culmination of gestation. In the present study, goats were fed yeast-supplemented diets for only $28 \pm 2$ days pre- and post-partum. One possible reason could be that the short duration of the current study might not have allowed the authors to observe the positive effects of maternal yeast inclusion on the birth weight and ADG of their kids.

The kids born to the goats fed with the yeast inclusion diet had similar serum glucose, urea nitrogen, cholesterol, total proteins, globulin, albumin globulin ratio, MDA, catalase, NEFA, and AST and ALT (Plumb, 2015) compared with the kids born to non-yeast supplemented goats. The current study agrees with that of Dabiri et al. (2016), who reported that suckling lambs of yeast-fed ewes had similar serum glucose, total protein and globulin to those of suckling lambs of non-yeast-fed ewes during the transition period. In contrast to the current study, Czech et al. (2009) reported increased blood urea nitrogen, increased catalase activity and lower cholesterol in suckling piglets of sows fed with yeast cell wall component (MOS) during late gestation and early lactation. However, Dabiri et al. (2016) reported lower urea nitrogen in the suckling lambs from yeast-fed ewes. Differences in these findings may be because of animal species (kids vs. piglets) composition of feed (live yeast as opposed to mannan oligosaccharides), environmental conditions, and physiological health status of animals and methods of supplementation.

\section{Conclusion}

Dietary inclusion of either 5 or 10 grams of yeast proved useful in improving milk yield, milk fat content and milk protein content of the goats during the transition period. Improvement in these parameters indicated a potential of yeast to reduce the stress of lactation in transition goats. Including yeast in the maternal diet during transition did not affect the growth and serum health biomarkers of their kids. Therefore, these results underline the need for further investigation to better understand the effects of a yeast-supplemented diet in goats and their suckling kids during transition. The inclusion of yeast could be more beneficial for high 
producing dairy goats or possibly goats that rear twin kids, which have greater demand for milk from the dam.

\section{Acknowledgements}

This work was sponsored by Higher Education Commission, Islamabad-Pakistan under Indigenous $5000 \mathrm{PhD}$ Fellowship Program to Shaista Abbas (Av7-046).

\section{Authors' Contributions}

SA, IR, HZ, MSY and HR conceived the project, designed the experiment, and analysed the data. AHS and MAR performed the experiment. SA and SA wrote the manuscript. HR, IR and HZ supervised the research. All authors read and approved the manuscript.

\section{Conflict of Interest Declaration}

The authors have no conflict of interest to declare.

\section{References}

Abd El-Ghani, A., 2004. Influence of diet supplementation with yeast culture (Saccharomyces cerevisiae) on performance of Zaraibi goats. Small Rumin. Res. 52, 223-229. DOI: 10.1016/j.smallrumres.2003.06.002

Abu El-Ella, A.A. \& Kommonna, O., 2013. Reproductive performance and blood constituents of Damascus goats as affected by yeast culture supplementation. Egypt. J. Sheep Goat Sci. 8, 171-187. DOI: 10.21608/EJSGS. 2013.26785

Alkass, J.E., Merkhan, K.Y. \& Hamo, R.A.H., 2013. Placental traits and their relation with birth weight in Meriz and Black goats. Sci. J. Anim. Sci. 2, 168-172.

AOAC, 2005. Official methods of analysis. 18th edition. Association of Official Analytical Chemists Inc., Arlington, Virginia, USA.

Bitencourt, L.L., Silva, J.R.M., Oliveira, B.M.L., Dias Júnior, G.S., Lopes, F., Siécola Júnior, S., Zacaroni, O.F. \& Pereira, M.N., 2011. Diet digestibility and performance of dairy cows supplemented with live yeast. Sci. Agric. 68, 301-307. DOI: $10.1590 / S 0103-90162011000300005$

Campanile, G., Zicarelli, F., Vecchio, D., Pacelli, C., Neglia, G., Balestrieri, A., Di Palo, R. \& Infascelli, F., 2008. Effects of Saccharomyces cerevisiae on in vivo organic matter digestibility and milk yield in buffalo cows. Livest. Sci.114, 358-361. DOI: 10.1016/j.livsci.2007.11.002

Czech, A., Mokrzycka, A., Grela, E.G. \& Pejsak, A., 2009. Influence of mannanoligosacharids additive to sow diets on blood parameters of sows and their piglets. Bull. Vet. Inst. Pulawy 53, 89-95.

Dabiri, N., Hajimohammadi, A., Mahdavi, A., Raghebian, M., Babaei, A. \& Bahrani, M., 2016. Effect of different levels of Biosaf probiotic in diet of late pregnant and lactating Iranian Zandi ewes, on growth performance and immune system of their lambs. Journal of Fisheries and Livestock Production 4, 207. DOI: 10.4172/2332-2608.1000207

Dolezal, P., Dolezal, J. \& Trinacty, J., 2005. The effect of Saccharomyces cerevisiae on ruminal fermentation in dairy cows. Czech J. Anim. Sci. 50, 503-510.

Drackley, J.K., Donkin, S.S. \& Reynolds, C.K., 2006. Major advances in fundamental dairy cattle nutrition. J. Dairy Sci. 89,1324-1336. DOI: 10.3168/jds.S0022-0302(06)72200-7

Erasmus, L.J., Botha, P.M. \& Kistner, A., 1992. Effect of yeast culture supplement on production, rumen fermentation and duodenal nitrogen flow in dairy cows. J. Dairy Sci. 75, 3056-3065. DOI: 10.3168/jds.S0022-0302(92)78069-2

Faubladier, C., Julliand, V., Danel, J. \& Philippeau, C., 2013. Bacterial carbohydrate-degrading capacity in foal faeces: Changes from birth to pre-weaning and the impact of maternal supplementation with fermented feed products. $\mathrm{Br}$. J. Nutr. 110, 1040-1052. DOI: 10.1017/S0007114512006162

Galip, N., 2006. Effect of supplemental yeast culture and sodium bicarbonate on ruminal fermentation and blood variables in rams. J. Anim. Phys. Anim. Nutri. 90, 446-452. DOI: 10.1111/j.1439-0396.2006.00625.x

Giger-Reverdin, S., Bezault, N., Sauvant, D. \& Bertin, G., 1996. Effects of a probiotic yeast in lactating ruminants: Interaction with dietary nitrogen level. Anim. Feed Sci. Technol. 63, 149-162. DOI: 10.1016/S03778401(96)01011-5

Guinard, J. \& Rulquin, H., 1994. Effect of graded levels of duodenal infusions of casein on mammary uptake in lactating cows. 1. Major nutrients. J. Dairy Sci. 77, 2221-2231. DOI: 10.3168/jds.S0022-0302(94)77271-4

Hansen, A, Lauridsen, C, Sørensen, M, Bach Knudsen, K.E. \& Theil, P.K., 2012. Effects of nutrient supply, plasma metabo-lites, and nutritional status of sows during transition on performance in the next lactation. J. Anim. Sci. 90, 466-480. DOI: $10.2527 /$ jas.2011-3984

Jenkins, T.C. \& McGuire, M.A., 2006. Major advances in nutrition: Impact on milk composition. J. Dairy Sci. 89, 13021310. DOI: $10.3168 /$ jds.S0022-0302(06)72198-1

Kaneko, J.J., Harvey, J.W. \& Bruss, M.L., 2008. Clinical biochemistry of domestic animals. 6th edition. Academic Press, San Diego, CA.

Lesmeister, K.E., Heinrichs, A.J. \& Gabler, M.T., 2004. Effects of supplemental yeast (Saccharomyces cerevisiae) culture on rumen development, growth characteristics, and blood parameters in neonatal dairy calves. J. Dairy Sci. 87, 1832-1839. DOI: 10.3168/jds.S0022-0302(04)73340-8

Ngwa, A.T., Dawson, L.J., Puchala, R., Detweiler, G.D., Merkel, R.C., Wang, Z., Tesfai, K., Sahlu, T., Ferrell, C.L. \& Goetsch, A.L., 2009. Effects of stage of lactation and dietary concentrate level on body composition of Alpine dairy goats. J. Dairy Sci. 92, 3374-85. DOI: 10.3168/jds.2009-2079 
Nocek, J.E. \& Kautz, W.P., 2014. Direct-fed microbial supplementation on ruminal digestion, health, and performance of pre- and postpartum dairy cattle. J. Dairy Sci. 89:260-266. DOI: 10.3168/jds.S0022-0302(06)72090-2.

Otuma, M.O. \& Osakwe, I.I., 2008. Estimation of genetic parameters of growth traits in Nigeria sahelian goats. Research J. Animal Sci. 2, 83-86. DOI=rjnasci. 2008.83.86

Poppy, G.D., Rabiee, A.R., Lean, I.J., Sanchez, W.K., Dorton, K.L. \& Morley, P.S., 2012. A meta-analysis of the effects of feeding yeast culture produced by anaerobic fermentation of Saccharomyces cerevisiae on milk production of lactating dairy cows. J. Dairy Sci. 95, 6027-6041. https://doi.org/10.3168/jds.2012-5577

Plumb, D.C., 2015. Plumb's veterinary drug handbook. 8th edition. Blackwell, Oxford, UK

Share, E.., 2015. Effects of maternal dietary yeast supplementation on foal growth and microbial diversity of the hindgut in quarter horse mares and their offspring. Master of Science, Ohio State University.

Salama, A.A.K., Caja, G., Garin, D., Albanell, E. \& Such, X., 2002. Effects of adding a mixture of malate and yeast culture (Saccharomyces cerevisiae) on milk production of Murciano-Granadiana dairy goats. Anim. Res. 51, 295303. DOI: 10.1051/animres:2002025

Stella, A.V., Paratte, R., Valnegri, L., Cigalino, G., Soncini, G., Chevaux, E., Dell'Orto, V. \& Savoini, G., 2007. Effect of administration of live Saccharomyces cerevisiae on milk production, milk composition, blood metabolites, and faecal flora in early lactating dairy goats. Small Rumin. Res. 67, 7-13. DOI: 10.1016/j.smallrumres.2005.08.024

Theil, P.K, Lauridsen, C. \& Quesnel, H., 2014. Neonatal piglet survival: Impact of sow nutrition around parturition on foetal glycogen deposition, and production and composition of colostrum and transient milk. Animal. 8, 10211030. DOI: $10.1017 / S 1751731114000950$

Wohlt, J.E., Corcione, T.T. \& Zajac, P.K., 1998. Effect of yeast on feed intake and performance of cows fed diets based on corn silage during early lactation. J. Dairy Sci. 81, 1345-1352. DOI: 10.3168/jds.S0022-0302(98)75697-8

Xie, C., Guo, X., Long, C., Fan, Z., Xiao, D., Ruan, Z., Deng, Z.Y., Wu, X. \& Yin, Y., 2015. Supplementation of the sow diet with chitosan oligosaccharide during late gestation and lactation affects hepatic gluconeogenesis of suckling piglets. Anim. Reprod. Sci. 159, 109-117. DOI: 10.1016/j.anireprosci.2015.06.004 